\title{
Chiari malformation and central sleep apnea syndrome: efficacy of treatment with adaptive servo-ventilation*
}

\author{
Malformação de Chiari e síndrome de apneia central do sono: \\ eficácia do tratamento com servoventilação adaptativa
}

\author{
Jorge Marques do Vale, Eloísa Silva, lsabel Gil Pereira, Catarina Marques, \\ Amparo Sanchez-Serrano, António Simões Torres
}

\begin{abstract}
The Chiari malformation type $1(\mathrm{CM}-1)$ has been associated with sleep-disordered breathing, especially central sleep apnea syndrome. We report the case of a 44-year-old female with $\mathrm{CM}-1$ who was referred to our sleep laboratory for suspected sleep apnea. The patient had undergone decompressive surgery 3 years prior. An arterial blood gas analysis showed hypercapnia. Polysomnography showed a respiratory disturbance index of 108 events/h, and all were central apnea events. Treatment with adaptive servo-ventilation was initiated, and central apnea was resolved. This report demonstrates the efficacy of servo-ventilation in the treatment of central sleep apnea syndrome associated with alveolar hypoventilation in a CM-1 patient with a history of decompressive surgery.
\end{abstract}

Keywords: Sleep apnea, central; Arnold-Chiari malformation; Noninvasive ventilation.

\section{Resumo}

A malformação de Chiari tipo 1 (MC-1) tem sido associada a distúrbios respiratórios do sono, sobretudo à síndrome de apneia central do sono. Apresentamos o caso de uma paciente do sexo feminino de 44 anos de idade com MC-1 que foi encaminhada a nossa unidade de sono por suspeita de apneia do sono. A paciente havia sido submetida a cirurgia descompressiva 3 anos antes. A gasometria arterial mostrou hipercapnia. A polissonografia revelou um índice de distúrbio respiratório de 108 eventos/h, sendo todos os eventos apneias centrais. Foi iniciado tratamento com servoventilação adaptativa e houve resolução da apneia central. Este relato demonstra a eficácia da servoventilação no tratamento da síndrome de apneia central do sono associada à hipoventilação alveolar em uma paciente com MC-1 previamente submetida a cirurgia descompressiva.

Descritores: Apneia do sono tipo central; Malformação de Arnold-Chiari; Ventilação não invasiva.

\section{Introduction}

The Chiari malformation type $1(\mathrm{CM}-1)$ is characterized by caudal displacement of the cerebellum and by herniation of the cerebellar tonsils through the foramen magnum. ${ }^{(1)}$ This malformation has been associated with sleepdisordered breathing, especially central sleep apnea syndrome. ${ }^{(2)}$ Treatment of symptomatic CM-1 consists of surgical decompression, which usually resolves the associated sleep-disordered breathing. ${ }^{(3)}$ We report a case of severe central sleep apnea syndrome in a female CM-1 patient with a history of decompressive surgery who was treated effectively with adaptive servoventilation (ASV).

\section{Case report}

A 44-year-old female patient diagnosed with CM-1 in 2008 (Figure 1A) underwent decompressive surgery of the posterior cranial fossa. She underwent suboccipital craniectomy, laminectomy of $\mathrm{C} 1$ and $\mathrm{C} 2$, and duraplasty. Her postoperative complications included cerebrospinal fluid fistula, which required reoperation and application of biological glue, and surgical wound infection, which was treated with debridement. Twelve months after surgery, the patient presented with worsening of neurological symptoms, including occipital headaches, dizziness, gait imbalance, left facial paresis, and dysphagia for liquids. Magnetic resonance imaging showed bony malformation

${ }^{*}$ Study carried out in the Department of Pulmonology, Tondela-Viseu Hospital Center, Viseu, Portugal.

Correspondence to: Jorge Marques do Vale. Serviço de Pneumologia, Centro Hospitalar Tondela-Viseu, Avenida Rei D. Duarte, CP 3509-304, Viseu, Portugal.

Tel. 35191 425-1943. E-mail: jorge_mvale@hotmail.com

Financial support: None.

Submitted: 23 September 2013. Accepted, after review: 20 November 2013. 
of the craniovertebral junction associated with a syringomyelic cavity involving C2 and C3 (Figure 1B). Additional surgical intervention was ruled out because of the associated risk of respiratory depression. Three years after surgery, the patient was referred to our sleep laboratory for suspected sleep apnea. She reported nonrestorative sleep and morning headaches, but she had no daytime sleepiness (Epworth score of 4) or symptoms suggestive of restless legs syndrome or narcolepsy. Additional information obtained from the patient's family confirmed the presence of snoring and witnessed apneas. The patient had a history of hypothyroidism and received levothyroxine regularly. She was a nonsmoker and did not drink alcohol.

Physical examination revealed that the patient had a body mass index of $34 \mathrm{~kg} / \mathrm{m}^{2}$, a systemic blood pressure of $127 / 73 \mathrm{mmHg}$, and a neck circumference of $46 \mathrm{~cm}$. In addition, she had a hypertrophic soft palate (Mallampati class 11), but she had no facial dysmorphisms. The remainder of the physical examination was normal.

A chest X-ray was unremarkable. There was no evidence of cardiovascular comorbidities (an echocardiogram and a Holter examination were unremarkable). Thyroid function was normal. An arterial blood gas analysis showed severe hypoxemia with mild hypercapnia $\left(\mathrm{FiO}_{2}=0.21\right.$; $\mathrm{pH}=7.35 ; \mathrm{PaO}_{2}=51 \mathrm{mmHg} ; \mathrm{PaCO}_{2}=56 \mathrm{mmHg}$; and $\mathrm{SaO}_{2}=89 \%$ ). Respiratory function test results

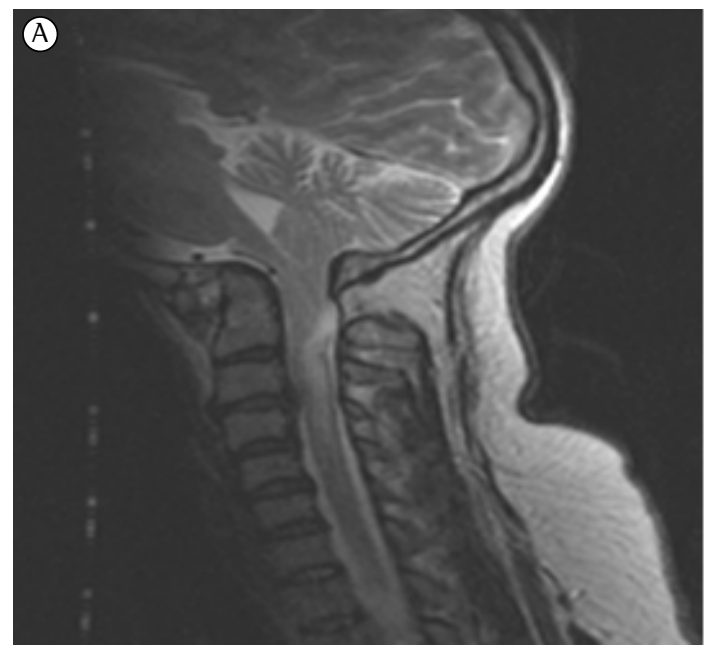

revealed a slight reduction in FVC, a reduction in expiratory reserve volume and a preserved TLC. Polysomnography showed low sleep efficiency (44.4\%), with 333 central respiratory events, a respiratory disturbance index of 108 events/h, and $27.6 \%$ of sleep time with oxyhemoglobin saturation $<90 \%$ (Figure 2).

The patient started treatment for central sleep apnea syndrome with ASV (S9 Autoset $\mathrm{CS}^{\mathrm{TM}}$; ResMed Corp., San Diego, CA, USA), with a maximum pressure support of $15 \mathrm{cmH}_{2} \mathrm{O}$, a minimum pressure support of $5 \mathrm{cmH}_{2} \mathrm{O}$, an expiratory pressure of $8 \mathrm{cmH}_{2} \mathrm{O}$, and an $\mathrm{RR}$ of 15 breaths/min. After six months of treatment, polysomnography under ASV showed that the respiratory disturbance index improved from 108 events/h to 4.8 events/ $h$ and that the patient spent $1.4 \%$ of sleep time with oxyhemoglobin saturation < 90\% (Figure 3). In addition, there was improvement in gas exchange $\left(\mathrm{FiO}_{2}=0.21\right.$; $\mathrm{pH}=7.36 ; \mathrm{PaO}_{2}=69 \mathrm{mmHg} ; \mathrm{PaCO}_{2}=46 \mathrm{mmHg} ;$ and $\mathrm{SaO}_{2}=93 \%$ ).

\section{Discussion}

The CM-1 has been defined as > 5-mm caudal displacement of the cerebellar tonsils through the foramen magnum and is usually associated with a volumetrically reduced posterior fossa. (1) For a diagnosis, these radiological criteria should be interpreted in the clinical context, and magnetic resonance imaging is the most useful

Figure 1 - In A, presurgical magnetic resonance imaging scan of the brain showing bony malformation of the craniovertebral junction associated with basilar impression and a shortened clivus. Low cerebellar tonsils (Chiari malformation type 1), but without evidence of syringomyelia. In B, postsurgical magnetic resonance imaging scan of the brain (T2) showing bony malformation of the craniovertebral junction associated with syringomyelia at the level of C2 and C3. 


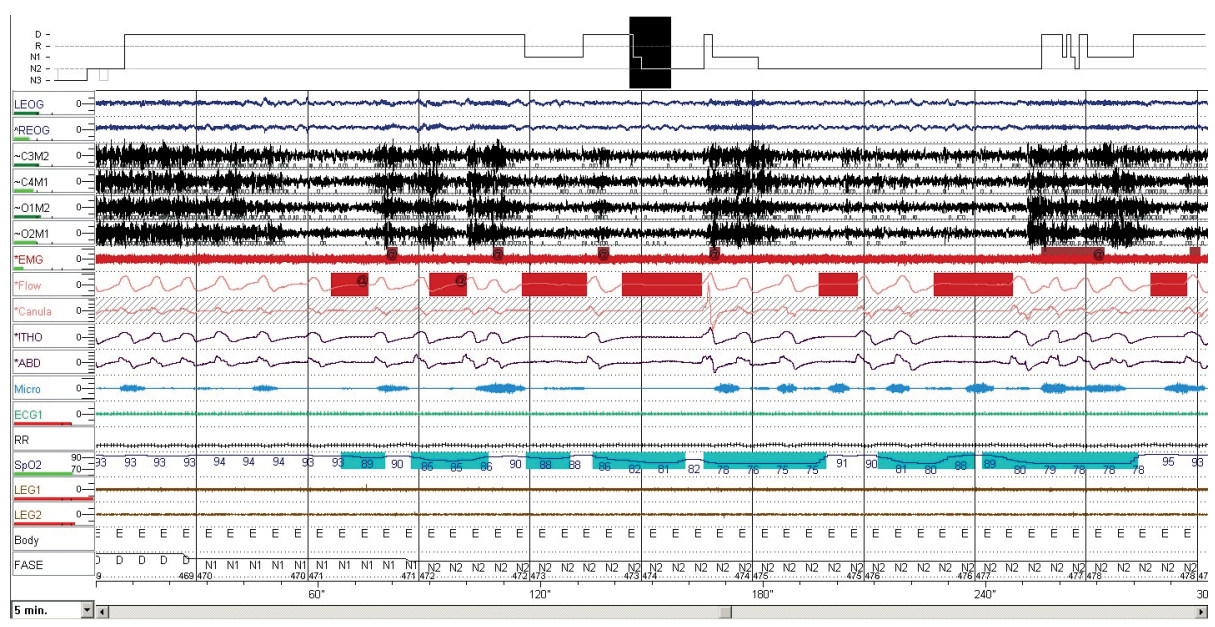

Figure 2 - Baseline polysomnogram showing central apneas.

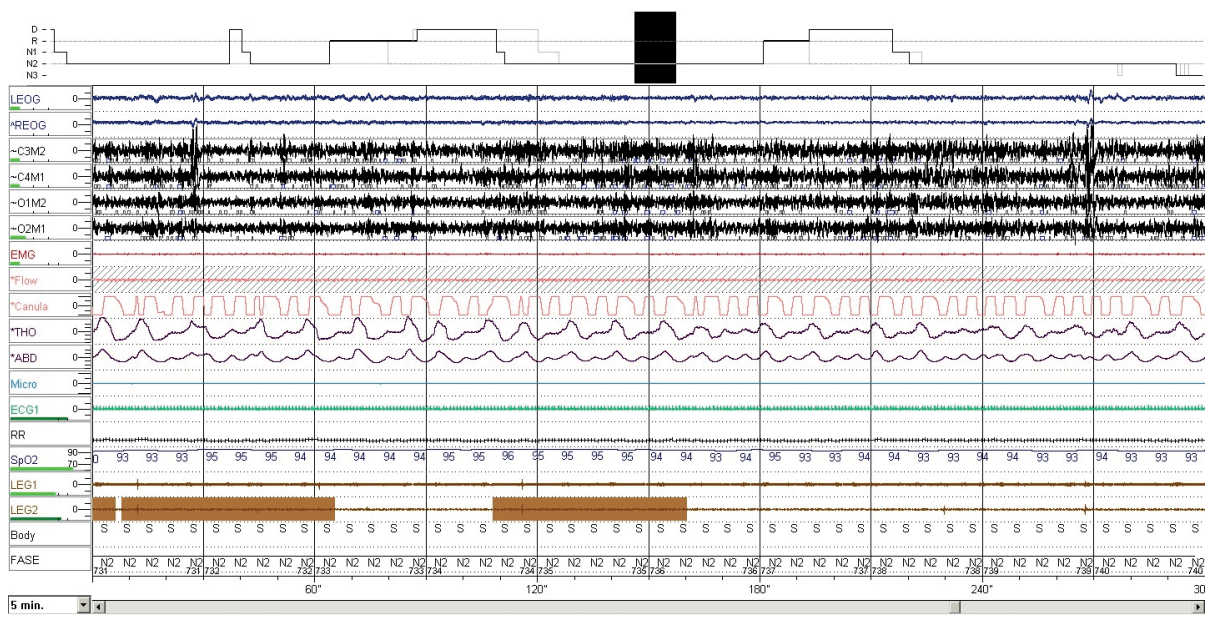

Figure 3 - Polysomnogram under servo-ventilation, showing resolution of the central apneas.

imaging tool. The respiratory center that controls breathing is located in the medulla oblongata, at the level of the craniocervical junction, and can be affected in this disease, thereby leading to respiratory disorders, especially during sleep. ${ }^{(4)}$ Studies in the literature have reported a high prevalence of sleep-disordered breathing in patients with CM. ${ }^{(5,6)}$ Although most reports in adults describe especially central sleep apneas, mixed and obstructive apneas are also seen. ${ }^{(7,8)}$ Central apneas might result from direct compression of the central respiratory components, compression of cranial nerve pairs IX and $X$, and afferent nerve lesion caused by syringomyelic cavities. ${ }^{(9)}$ Hypoventilation is defined as sustained oxygen desaturation that is not associated with obstructive apneas, hypopneas, or periodic breathing. ${ }^{(10)}$ Patients with daytime hypercapnia, mainly because of neuromuscular disease or ventilatory control abnormalities (obesity hypoventilation syndrome and central alveolar hypoventilation), may also have central apneas during sleep. ${ }^{(11)}$ Central events are characterized by a temporary cessation of the neural respiratory drive during sleep, resulting in a decrease in ventilation and changes in gas exchange. ${ }^{(12)}$ In general, central apneas during sleep in patients with hypercapnia should be distinguished from those occurring in patients with normocapnia or hypocapnia. Hypercapnic central sleep apnea overlaps with hypoventilation syndromes and is considered an integral part of sleep hypoventilation syndrome. ${ }^{(11)}$

In the case described here, there were changes in respiratory function, including a slight reduction in FVC accompanied by a reduction in expiratory reserve volume. In obese patients, 
there is respiratory mechanics impairment that causes changes in pulmonary function, such as increased work of breathing and reduced lung volumes. The ventilatory restriction imposed by obesity is usually mild and is attributed to the mechanical effects that accumulation of adipose tissue has on the diaphragm and chest wall: diaphragmatic excursion is impaired and chest compliance is decreased. ${ }^{(13)}$ The reduction in expiratory reserve volume may be detectable even in modestly overweight patients. In patients with morbid obesity, this change may be accompanied by a reduction in TLC and functional residual capacity. ${ }^{(14)}$ Some obese patients have alveolar hypoventilation. The mechanism through which obesity leads to hypoventilation is complex and has yet to be fully understood. Several mechanisms have been proposed, including changes in respiratory mechanics, decreased central responses to hypercapnia and hypoxia, and neurohormonal changes, such as resistance to leptin. ${ }^{(15)}$ Obesity hypoventilation syndrome is defined as a combination of obesity (body mass index $\geq 30 \mathrm{~kg} / \mathrm{m}^{2}$ ), daytime hypercapnia, and different types of sleep-disordered breathing in the absence of other conditions that may cause alveolar hypoventilation (obstructive or restrictive lung diseases, diseases of the chest wall, and neuromuscular diseases). ${ }^{(16)}$ Patients with neurological disorders, including CM, may have central hypoventilation. ${ }^{(17)}$ However, alveolar hypoventilation associated with central apneas is not common in CM-l, and, in the present case, it is not possible to exclude the role of obesity in the changes found on arterial blood gas analysis.

Decompressive surgery usually results in a decreased number of respiratory events during sleep and reduces sleep fragmentation in a significant number of patients, with the effects being more pronounced in those with central apneas. ${ }^{(3)}$ However, there are reports of the emergence of central apneas after surgery. ${ }^{(18)}$

ASV is a form of closed-loop mechanical ventilation, pressure preset, and volume or flow cycled. It alleviates central apneas by providing dynamic (breath-by-breath) adjustment of inspiratory pressure support with a back-up rate to normalize breathing patterns. The efficacy of ASV has been established especially in the treatment of central sleep apnea syndrome associated with congestive heart failure. In central sleep apnea syndrome associated with neurological disorders (without Cheyne-Stokes respiration), the role of ASV has yet to be well established. ${ }^{(19)}$

The clinical case reported here demonstrates the efficacy of ASV in the treatment of central sleep apnea syndrome associated with alveolar hypoventilation in a CM-1 patient, since there was complete resolution of the central events and a significant improvement in gas exchange. In addition, the case suggests that ASV may be efficacious in the treatment of central sleep apnea in CM-1 patients with a history of decompressive surgery. We have found only one similar case reported in the published literature. ${ }^{(20)}$ In conclusion, ASV may be an alternative to decompressive surgery in the treatment of central sleep apnea in CM-1 patients.

\section{Acknowledgments}

We would like to thank Dr. Nuno Canto Moreira for his contribution in the analysis of the magnetic resonance imaging scans.

\section{References}

1. Zolty P, Sanders MH, Pollack IF. Chiari malformation and sleep-disordered breathing: a review of diagnostic and management issues. Sleep. 2000;23(5):637-43. PMid:10947031

2. Lam B, Ryan CF. Arnold-Chiari malformation presenting as sleep apnea syndrome. Sleep Med. 2000;1(2):139-44. http://dx.doi.org/10.1016/S1389-9457(99)00004-0

3. Gagnadoux F, Meslier N, Svab 1, Menei P, Racineux Jl. Sleep-disordered breathing in patients with Chiari malformation: improvement after surgery. Neurology. 2006;66(1):136-8. http://dx.doi.org/10.1212/01. wnl.0000191394.53786.62

4. Botelho RV, Bittencourt LR, Rotta JM, Tufik S. Adult Chiari malformation and sleep apnoea. Neurosurg Rev. 2005;28(3):169-76. http://dx.doi.org/10.1007/ s10143-005-0400-y

5. Botelho RV, Bittencourt LR, Rotta JM, Tufik S. The effects of posterior fossa decompressive surgery in adult patients with Chiari malformation and sleep apnea. J Neurosurg. 2010;112(4):800-7. http://dx.doi. org/10.3171/2009.7.JNS09174

6. Botelho RV, Bittencourt LR, Rotta JM, Tufik S. Polysomnographic respiratory findings in patients with Arnold-Chiari type 1 malformation and basilar invagination, with or without syringomyelia: preliminary report of a series of cases. Neurosurg Rev. 2000;23(3):151-5. http:// dx.doi.org/10.1007/PL00011947

7. Bittencourt LR, Botelho RV, Moura SM, Nery LE, Palombini LO. Síndrome da apneia do sono central e dor cervical. J Pneumol. 1996;22(2):93-4.

8. Becker HF. Adult Chiari malformation and sleep apnoea. Neurosurg Rev. 2005;28(3):177-8. http://dx.doi. org/10.1007/s10143-005-0401-x 
9. Botelho RV, Bittencourt LR, Rotta JM, Tufik S. A prospective controlled study of sleep respiratory events in patients with craniovertebral junction malformation. J Neurosurg. 2003;99(6):1004-9. http://dx.doi.org/10.3171/ jns.2003.99.6.1004

10. Kushida CA, Littner MR, Morgenthaler T, Alessi CA, Bailey D, Coleman J Jr, et al. Practice parameters for the indications for polysomnography and related procedures: an update for 2005. Sleep. 2005;28(4):499-521. PMid:16171294

11. Eckert DJ, Jordan AS, Merchia P, Malhotra A. Central sleep apnea: Pathophysiology and treatment. Chest. 2007;131(2):595-607. http://dx.doi.org/10.1378/ chest.06.2287

12. White DP. Pathogenesis of obstructive and central sleep apnea. Am J Respir Crit Care Med. 2005;172(11):136370. http://dx.doi.org/10.1164/rccm.200412-1631S0

13. Jones RL, Nzekwu MM. The effects of body mass index on lung volumes. Chest. 2006;130(3):827-33. http:// dx.doi.org/10.1378/chest.130.3.827

14. Salome CM, King GG, Berend N. Physiology of obesity and effects on lung function. J Appl Physiol (1985). 2010;108(1):206-11. http://dx.doi.org/10.1152/ japplphysiol.00694.2009
15. Mokhlesi B. Obesity hypoventilation syndrome: a stateof-the-art review. Respir Care. 2010;55(10):1347-62; discussion 1363-5. PMid:20875161

16. Al Dabal L, Bahammam AS. Obesity hypoventilation syndrome. Ann Thorac Med. 2009;4(2):41-9. http:// dx.doi.org/10.4103/1817-1737.49411

17. Phillipson EA, Duffin J. Hypoventilation and hyperventilation syndromes. In: Mason RJ, Broaddus VC, Murray JF, Nadel JA, editors. Murray and Nadel's Textbook of Respiratory Medicine. 4th ed. Philadelphia, PA: Saunders; 2005; p. 2069-90.

18. Paul KS, Lye RH, Strang FA, Dutton J. Arnold-Chiari malformation. Review of 71 cases. J Neurosurg. 1983;58(2):183-7. http://dx.doi.org/10.3171/ jns.1983.58.2.0183

19. Aurora NR, Chowduri S, Ramar K, Bista SR, Casey KR, Lamm $\mathrm{Cl}$, et al. The treatment of central sleep apnea syndrome in adults: practice parameters with an evidence-based literature review and meta-analyses. Sleep. 2012;35(1):1740. http://dx.doi.org/10.5665/sleep. 1580

20. Fahim A, Johnson AO. Chiari malformation and central sleep apnoea: successful therapy with adaptive pressure support servo-ventilation following surgical treatment. BMJ Case Rep. 2012; 2012. pii: bcr-2012-007143. http:// dx.doi.org/10.1136/bcr-2012-007143.

\section{About the authors}

\section{Jorge Marques do Vale}

Intern in Pulmonology. Tondela-Viseu Hospital Center, Viseu, Portugal.

\section{Eloísa Silva}

Intern in Pulmonology. Tondela-Viseu Hospital Center, Viseu, Portugal.

\section{Isabel Gil Pereira}

Pulmonologist. Tondela-Viseu Hospital Center, Viseu, Portugal.

\section{Catarina Marques}

Neurosurgeon. Tondela-Viseu Hospital Center, Viseu, Portugal.

\section{Amparo Sanchez-Serrano}

Pulmonologist. Tondela-Viseu Hospital Center, Viseu, Portugal.

\section{António Simões Torres}

Pulmonologist. Tondela-Viseu Hospital Center, Viseu, Portugal. 